\title{
Impact of Advanced HIV Disease on Quality of Life and Mortality in the Era of Combined Antiretroviral Treatment
}

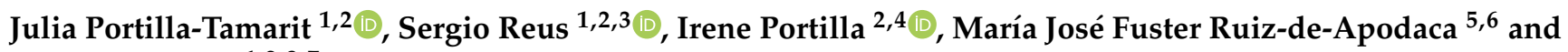 \\ Joaquín Portilla $1,2,3,7, *$
}

check for

updates

Citation: Portilla-Tamarit, J.; Reus, S.; Portilla, I.; Fuster Ruiz-de-Apodaca, M.J.; Portilla, J. Impact of Advanced HIV Disease on Quality of Life and Mortality in the Era of Combined Antiretroviral Treatment. J. Clin. Med. 2021, 10, 716. https://doi.org/ $10.3390 / \mathrm{jcm} 10040716$

Academic Editor: Silvia Nozza

Received: 8 December 2020

Accepted: 8 February 2021

Published: 11 February 2021

Publisher's Note: MDPI stays neutral with regard to jurisdictional claims in published maps and institutional affiliations.

Copyright: (c) 2021 by the authors. Licensee MDPI, Basel, Switzerland. This article is an open access article distributed under the terms and conditions of the Creative Commons Attribution (CC BY) license (https:/ / creativecommons.org/licenses/by/ $4.0 /)$.
1 Infectious Diseases Unit, Internal Medicine Department, Alicante University General Hospital, 03010 Alicante, Spain; jpt.julia@gmail.com (J.P.-T.); reus_ser@gva.es (S.R.)

2 Alicante Institute for Health and Biomedical Research (ISABIAL), 03010 Alicante, Spain; irene.portilla@ua.es

3 Department of Clinical Medicine, Miguel Hernandez University, 03207 Elche, Alicante, Spain

4 Department of Health Psychology, University of Alicante, 03690 Alicante, Spain

5 Psicología Social y de las Organizaciones, Facultad de Psicología, National Distance Learning University (UNED), 28015 Madrid, Spain; gerencial@seisida.net

6 Spanish Interdisciplinary AIDS Society (SEISIDA), 28036 Madrid, Spain

7 Spanish AIDS Research Network, Carlos III Health Institute, 28029 Madrid, Spain

* Correspondence: portilla_joa@gva.es

Abstract: Currently, AIDS or severe immunodeficiency remains as a challenge for people with HIV (PWHIV) and healthcare providers. Our purpose was to analyze the impact of advanced HIV disease (AHD) on mortality, life expectancy and health-related quality of life (HRQoL). We reviewed cohort studies and meta-analyses conducted in middle- and high-income countries. To analyze HRQoL, we selected studies that reported overall health and/or physical/mental health scores on a validated HRQoL instrument. AIDS diagnosis supposes a higher risk of mortality during the first six months, remaining higher for 48 months. It has been reported that cancer and cardiovascular disease persist as frequent causes of mortality in PWHIV, especially those with previous or current AHD. PWHIV who initiate combination antiretroviral therapy (cART) with CD $<200$ cells / $\mu$ L have significantly lower estimated life expectancy than those with higher counts. AHD is associated with lower HRQoL, and a worse physical health or mental health status. AIDS and non-AIDS defining events are significant predictors of a lower HRQoL, especially physical health status. AHD survivors are in risk of mortality and serious comorbidities, needing special clinical attention and preventive programs for associated comorbidities. Their specific needs should be reflected in HIV guidelines.

Keywords: immunodeficiency; HIV/AIDS; mortality; quality of life of healthcare

\section{Introduction}

In the early years of the human immunodeficiency virus (HIV) pandemic, acquired immunodeficiency syndrome (AIDS) was a fatal condition accompanied by severe opportunistic diseases, with physical symptoms such as wasting, diarrhea, fever, and a short-time mortality. In addition, people living with HIV (PWHIV) suffered social isolation, internalized stigma, problems related to drug abuse, depression, anxiety, and other psychosocial conditions [1]. With the advent of high-activity antiretroviral therapy (HAART) in 1996, AIDS mortality decreased dramatically, although serious adverse events secondary to the new antiretroviral drugs began to surface. The HIV population who survived to AIDS, known as long-term survivors [2], frequently suffer a constellation of medical, psychological, and emotional disorders, and low quality of life related to health (HRQoL) $[3,4]$.

Despite improvements in early HIV diagnosis and global efforts to deliver combination antiretroviral therapy (cART), many patients are still at risk of advanced HIV disease (AHD). The Joint United Nations Program on HIV / AIDS (UNAIDS) reported that at the end of 2018, around 770,000 (uncertainty bounds, 570,000-1.1 million) people died from AIDSrelated illnesses worldwide [5]. In 2017, the European Centre for Disease Control reported 
3130 AIDS diagnoses in the 28 European Union/European Economic Area (EU/EEA) countries, giving a crude rate of 0.7 cases per 100,000 of the population [6].

AHD continues to have a negative impact among some PWHIV, despite antiretroviral therapy [7]. Currently, surviving to AHD can be a real challenge for some PWHIV and their healthcare providers. Our aim is to review the impact of AHD on mortality and HRQoL in PWHIV living in countries with easy access to cART.

\section{Methodology}

Our population of interest was people diagnosed with AHD. We used the stage 3 definition of HIV disease from the Centers for Disease Control and Prevention (CDC), which includes those PWHIV with AIDS or CD $4<200$ cells $/ \mu \mathrm{L}$ [8]. For the objectives of this article, we reviewed the scientific literature in PubMed and Google Scholar in English language journals before July 2020, with the condition that most of the study should have been carried out during the 21st century and started after the availability of HAART (1996). We selected cohort studies and meta-analyses conducted in middleand high-income countries with universal access to cART and to healthcare. To identify independent determinants of mortality, loss of life expectancy, and perceived HRQoL, articles had to report appropriate statistics, especially a multivariate regression analysis on the association between AHD and the corresponding endpoint variables. Moreover, to analyze HRQoL, we selected cross-sectional and longitudinal studies that reported overall health and/or physical/mental health scores on a validated HRQoL instrument.

We searched for the terms "mortality", "life expectancy", "cancer", "cardiovascular disease" and "health-related quality of life". Each term was crossed with "AIDS diagnosis" or "advanced HIV disease" or "CD4 cells".

The main reasons to exclude articles were: (1) did not strictly comply with inclusion criteria; (2) did not include patients with AHD or CD4+ lymphocyte counts below $200 / \mu \mathrm{L}$; and (3) did not include multivariable analysis about the subject of researching. We decided not to review liver disease due to hepatitis $\mathrm{C}$ virus (HCV), because the currently available high-active antiviral agents against $\mathrm{HCV}$ are decreasing the incidence, morbidity and mortality of serious liver disease in PWHIV.

\section{Results}

\subsection{Factors Associated to AHD or Progression to AIDS}

Studies conducted in high-income countries showed that the populations most likely to present for care with AHD are men, heterosexuals, older people, people who inject drugs, migrants, people suffering socioeconomic inequalities, and people with lower educational levels $[9,10]$.

Factors associated with progression to AHD are social (previous incarceration, noncontinuity in HIV care) and immunovirological outcomes (low CD4+ count, poor CD4+ response to therapy, drug resistance). The adjusted risk for progression to AIDS associated with a poor CD4+ recovery (discordant immunovirological response to treatment) was as high as $2.70(95 \%$ CI 1.29-5.66) in some studies [11-14].

\subsection{Life Expectancy and Mortality in AHD Patients}

Life expectancy in PWHIV on cART has improved worldwide, but an important gap remains compared with the general population [15]. PWHIV at higher risk of mortality in Western countries include people who inject drugs, people living in resourceconstrained settings, and people who are highly stigmatized or who face other barriers such as depression and other mental disorders, access to health services, unemployment, family responsibilities, and so on $[5,11,15,16]$.

In our review, we included 14 studies (Table 1): three analyzed life expectancy, and 11 explored mortality associated with AIDS defining-events (ADEs) and non-AIDS defining-events (NADEs). All of them were cohort studies and were mainly conducted in 
high-income Western countries (Europe and North America), but one included patients from Israel and Argentina.

Cohort studies are quite homogeneous in this regard. Results from longitudinal cohort studies published during the 21st century demonstrate that even on cART, patients with AHD have an increased risk of mortality related with AIDS and non-AIDS events. PWHIV who initiate cART with CD4 $<200$ cells / $\mu$ L have significantly lower estimated life expectancies [16-18] and a higher risk of mortality by ADEs and NADEs than those with higher counts [19-22]. Patients presenting for care with AIDS have a higher risk of mortality during the first six months, and it persists higher during the 48 months after AIDS diagnosis compared with those without previous AIDS [23,24]. After surviving five years with cART, the mortality of patients who started cART with a low baseline CD4 count converged with mortality of patients with intermediate and high baseline CD4 counts [25]. In addition, most of the cohort studies agree that starting CART with higher CD4 counts decrease mortality in PWHIV [26-29]. These results are independents of gender, age, and type or number of comorbidities (Table 1).

Table 1. Impact of advanced HIV disease on life expectancy and mortality.

\begin{tabular}{|c|c|c|c|c|}
\hline Reference & $\begin{array}{l}\text { Methodology } \\
\text { (Cohort Name) }\end{array}$ & Population & Study Period & $\begin{array}{l}\text { Impact of Advanced HIV Disease } \\
\text { on Mortality and Life Expectancy }\end{array}$ \\
\hline \multicolumn{5}{|c|}{ Estimated life expectancy } \\
\hline Hogg [16] & $\begin{array}{l}\text { Cohort study } \\
\text { (ART-CC) }\end{array}$ & $\begin{array}{l}\text { Europe/North- } \\
\text { America }\end{array}$ & 1996-2005 & $\begin{array}{l}\text { Expected age at death (years) } \\
\text { in } 20 \text {-year-olds with CD4 count } \\
<100 \text { cells } / \mu \mathrm{L}, 100-199 \\
\text { cells } / \mu \mathrm{L} \text { and } \geq 200 \text { cells } / \mu \mathrm{L} \text { : } \\
32.4(\mathrm{SE}, 1.1), 42.0(0.62) \text { and } \\
50.4(0.41), \text { respectively. }\end{array}$ \\
\hline May [18] & $\begin{array}{l}\text { Cohort study } \\
\text { (UK-CHIC) }\end{array}$ & United Kingdom & 2000-2010 & $\begin{array}{l}\text { - Expected age at death (years) } \\
\text { at the start of ART in } \\
\text { 35-year-olds with CD4 count } \leq \\
200 \text { cells / } \mu \mathrm{L} \text { and } 200-349 \\
\text { cells / } \mu \mathrm{L} \text { : } 71 \text { (95\% CI, 68-73) } \\
\text { and } 78 \text { (74-82), respectively. } \\
\text { Expected age of death (years) } \\
\text { after } 5 \text { years on ART in } \\
\text { 35-year-olds with CD4 count < } \\
200 \text { cells / } \mu \mathrm{L} \text { and no viral } \\
\text { suppression, and CD4 count } \geq \\
350 \text { cells / } \mu \mathrm{L} \text { and viral } \\
\text { suppression: } 54 \text { (95\% CI, 48-61) } \\
\text { and } 80 \text { (76-83), respectively. }\end{array}$ \\
\hline Losina [17] & $\begin{array}{l}\text { Cohort study } \\
\text { (HIV-Research- } \\
\text { Network) }\end{array}$ & United States & $2009 *$ & $\begin{array}{l}\text { - Life expectancy in years from } \\
\text { age } 33 \text { (and additional years } \\
\text { lost compared to starting ART } \\
\text { with CD4 count } \geq 200 \\
\text { cells } / \mu \mathrm{L} \text { ) in patients with CD4 } \\
\text { count } \leq 200 \text { cells } / \mu \mathrm{L} \text { and }<50 \\
\text { cells } / \mu \mathrm{L}: 18.75 \text { (3.90) and } 13.82 \\
\text { (8.83), respectively. }\end{array}$ \\
\hline
\end{tabular}


Table 1. Cont.

\begin{tabular}{|c|c|c|c|c|}
\hline Reference & $\begin{array}{l}\text { Methodology } \\
\text { (Cohort Name) }\end{array}$ & Population & Study Period & $\begin{array}{l}\text { Impact of Advanced HIV Disease } \\
\text { on Mortality and Life Expectancy }\end{array}$ \\
\hline \multicolumn{5}{|c|}{ Mortality associated with AIDS } \\
\hline $\begin{array}{l}\text { Montha-luc } \\
\text { [24] }\end{array}$ & $\begin{array}{l}\text { Cohort study } \\
\quad \text { (ANRS) }\end{array}$ & France & 2003-2009 & $\begin{array}{l}\text { Risk of death, expressed in } \\
\text { aHR }(95 \% \mathrm{CI}), \text { in patients } \\
\text { presenting with AIDS during } \\
\text { first } 6 \text { months of follow-up and } \\
\text { during months } 12 \text { to } 48 \text { was } \\
48.3(28.0-83.5) \text { and } 4.8 \\
\text { (3.3-7.0), respectively. } \\
\text { Corresponding values among } \\
\text { AIDS-free patients with CD4 } \\
\text { count } \leq 200 \text { cells } / \mu \mathrm{L} \text { were } 8.1 \\
(4.5-14.6) \text { and } 2.3(1.6-3.4) \text {. }\end{array}$ \\
\hline Mocroft [23] & $\begin{array}{l}\text { Cohort study } \\
\text { (COHERE) }\end{array}$ & Europe & 2000-2011 & $\begin{array}{l}\text { Increased rate of AIDS/death } \\
\text { beyond two years after } \\
\text { diagnosis in people presenting } \\
\text { for care with AHD in southern } \\
\text { Europe (aIRR, 1.38; } 95 \% \text { CI, } \\
\text { 1.01-1.88) and in eastern } \\
\text { Europe in the first year (aIRR, } \\
6.98 ; 95 \% \text { CI, } 4.22-11.56 \text { ). }\end{array}$ \\
\hline
\end{tabular}

Mortality associated with CD4 count

$\begin{array}{lll}\text { Baker [26] Cohort study } & \text { U.S.A. }\end{array}$

- $\quad$ Reduction $(\%)$ in risk resulting from each increase of 100 cell $/ \mu \mathrm{L}$ in CD4 count was $44 \%$ (95\% CI for HR, 0.50-0.62) for AIDS; $14 \%(0.77-0.96)$ for NADEs; 35\% (0.59-0.72) for death by any cause; and 30\% (0.65-0.75) for the composite outcome of AIDS/non-AIDS event/death.

- $\quad$ Reduction (\%) in risk resulting from each increment of 100 cells $/ \mu \mathrm{L}$ in the CD4 count was $32 \%(95 \%$ CI, 28-35) for $\begin{array}{lll}\text { Marin [27] } & \begin{array}{l}\text { Cohort study } \\ \text { (CASCADE) }\end{array} \quad \text { Europe/Canada } & \text { 1996-2006 }\end{array}$ all-cause mortality; 64\% (58-69) for ADEs; 33\% (18-46) for end-stage liver disease; and $34 \%(21-45 \%)$ for NADC. 
Table 1. Cont.

\begin{tabular}{|c|c|c|c|c|}
\hline Reference & $\begin{array}{l}\text { Methodology } \\
\text { (Cohort Name) }\end{array}$ & Population & Study Period & $\begin{array}{l}\text { Impact of Advanced HIV Disease } \\
\text { on Mortality and Life Expectancy }\end{array}$ \\
\hline Mocroft [28] & $\begin{array}{l}\text { Cohort study } \\
\text { (EUROSIDA) }\end{array}$ & Europe/Israel/Argentina & 2001-2009 & $\begin{array}{l}\text { Reduction in risk due to } \\
\text { doubling of CD4 count, } \\
\text { represented by adjusted IRR } \\
(95 \% \text { CI), was } 0.63(0.60-0.66) \\
\text { for ADEs; } 0.80(0.75-0.85) \text { for } \\
\text { NADEs, } 0.78(0.69-0.87) \text { for } \\
\text { NADC; } 0.70(0.57-0.80) \text { for } \\
\text { ESRD; } 0.73(0.65-0.83) \text { for } \\
\text { liver-related events. } \\
\text { The reduction in risk of } \\
\text { cardiovascular events was not } \\
\text { significant (IRR, } 0.98 ; 95 \% \text { CI, } \\
\text { 0.85-1.12). }\end{array}$ \\
\hline Young [29] & $\begin{array}{l}\text { Cohort study } \\
\text { (COHERE) }\end{array}$ & Europe & 1997-2010 & $\begin{array}{l}\text { - HR for new AIDS event or } \\
\text { death in people with } \\
\text { CD4 }<200 / \mu / \mathrm{L}, 200-350 / \mu / \mathrm{L} \\
\text { and } 350-500 / \mu \mathrm{L} \text { was } 0.35(95 \% \\
\mathrm{CI}, 0.30-0.40), 0.74(0.66-0.83) \\
\text { and } 0.96(0.92-0.99), \\
\text { respectively. }\end{array}$ \\
\hline
\end{tabular}

- $\quad$ Adjusting for other prognostic factors and comparing baseline CD $4<50$ cells $/ \mu \mathrm{L}$ with 200-349 cells / $\mu$ L during the first 6 months of ART, MRR

May [25] Cohort study

(ART-CC)

urope/North-

America

1996-2013

was 2.81 (95\% CI, 2.12-3.71) declining to 1.59 (1.31-1.92) 3 to 4.9 years after the start of ART.

- $\quad$ Little evidence that baseline CD4 count was prognostic for mortality after 5 years of cART.
SobrinoVegas [20]

Cohort study (CO-RIS)

Spain

2004-2013
- $\quad$ aHR for all-cause mortality in people with CD4 count $\leq$ 200 cells $/ \mu$ L without AIDS and people with AIDS was $5.6(95 \%$ CI, 2.7-11.9) and 22.6 (11.5-44.6), respectively.

- $\quad$ CD4 count at death was lowest for those who died of AIDS-related causes, with a median of 48 cells $/ \mu \mathrm{L}$ (IQR, 13-140), and highest for those who died of CVD (360; 221-608) and unnatural causes (340; 150-560). 
Table 1. Cont.

\begin{tabular}{|c|c|c|c|c|}
\hline Reference & $\begin{array}{l}\text { Methodology } \\
\text { (Cohort Name) }\end{array}$ & Population & Study Period & $\begin{array}{l}\text { Impact of Advanced HIV Disease } \\
\text { on Mortality and Life Expectancy }\end{array}$ \\
\hline \multicolumn{5}{|c|}{ Mortality associated with NADEs } \\
\hline Zhang [19] & $\begin{array}{l}\text { Cohort study } \\
\text { (ATHENA) }\end{array}$ & Netherlands & 1998-2012 & $\begin{array}{l}\text { RR of composite } \\
\text { non-AIDS-related endpoint } \\
\text { (major CVDs, liver } \\
\text { fibrosis/cirrhosis, and } \\
\text { non-AIDS-related } \\
\text { malignancies) was } 4.71(95 \% \\
\text { CI, } 2.98-7.45) \text { for people with } \\
\text { CD4 count }<200 \text { cells } / \mu \mathrm{L}, \text { vs. } \\
1.19(0.82-1.74) \text { for people with } \\
\text { CD4 of 350-499 cells / } \mu \mathrm{L} \text {; and } \\
2.89(1.79-4.64) \text { for those with a } \\
\text { CDC-C event vs. } 1.98 \\
\text { (1.23-3.20) for those with a } \\
\text { CDC-B event. }\end{array}$ \\
\hline Pettit [21] & Cohort study & Europe/North America & 1996-2014 & $\begin{array}{l}\text { Risk of overall non-AIDS } \\
\text { mortality was higher in } \\
\text { patients with vs. without ADE } \\
\text { (aHR, 2.21; } 95 \% \text { CI, 2.00-2.43). }\end{array}$ \\
\hline
\end{tabular}

* year of publication. ADE: AIDS-defining event; aHR: adjusted hazard ratio; aIRR: adjusted incidence rate ratio; ART: antiretroviral therapy; cART: combination antiretroviral therapy; CDC: Centers for Disease Control and Prevention; cHR crude hazard ratio; CI: confidence interval; CVD: cardiovascular disease; ESRD: end-stage renal disease; HR: hazard ratio; IQR: interquartile range; IRR: incidence rate ratio; MHR: mortality hazard ratio; MRR: mortality rate ratio; NADC: non-AIDS defining cancer; NADE: non-AIDS-defining event; RR: relative risk; SE: standard error.

\subsection{Cancer Incidence and Related Mortality in PWHIV with AHD}

Excess of mortality in PWHIV, comparing with the general population of the same sex and age, has been observed in non-AIDS cancer, cardiovascular disease, respiratory diseases, liver diseases, drug abuse, suicide, and other external causes [15]. The more frequent NADEs driving to mortality with previous AIDS or $<200 \mathrm{CD} 4 / \mu \mathrm{L}$ are malignancies, cardiovascular and end-stage liver disease $[19,27,28]$ (Table 1).

Cancers in PWHIV are classified as either AIDS-defining cancers (ADC) or nonAIDS defining cancers (NADC) that includes those related to virus infections (NADCI). We analyzed eight studies on the impact of AHD on cancer development; five were large cohort studies, two were extracted from a Cancer National Registry, and one was a metaanalysis. All of them separately analyzed ADC and NADC in people with previous AIDS or CD4 $<200 /$ cells $/ \mu \mathrm{L}$. Data from these studies demonstrate the strong association between AHD and increased cancer risk in PWHIV (Table 2).

Low CD4 cell count is an independent predictor of developing ADC and NADCI: Kaposi sarcoma, non-Hodgkin lymphoma [30-33], anal cancer and Hodgkin lymphoma [34-37]. Data from the ATHENA cohort associate cumulative exposure to CD4 $<200$ cells $/ \mu \mathrm{L}$ during cART with increased risk of NADCI [37]. Previous AIDS diagnosis is also a risk factor of cancer, compared with those with non-AIDS [36]. Results on the association between AHD and NADC are discordant (Table 2). Some studies show an association between AHD and lung cancer, colorectal and oral cavity/pharynx cancer [31,35], while other studies find no associations [30]. 
Table 2. Impact of advanced HIV disease on cancer incidence.

\begin{tabular}{|c|c|c|c|c|}
\hline Reference & $\begin{array}{c}\text { Design } \\
\text { (Cohort Name) }\end{array}$ & Population & Study Period & $\begin{array}{c}\text { Impact of Advanced HIV Disease on } \\
\text { Cancer Incidence }\end{array}$ \\
\hline Bedimo [34] & $\begin{array}{l}\text { Cancer Registry } \\
\text { (U.S. Veterans-Affairs) }\end{array}$ & U.S.A. & 1997-2004. & $\begin{array}{l}\text { - Median CD4 counts (cells / } \mu \mathrm{L}) \\
\text { were significantly lower for } \\
\text { PWHIV with NADC (249 vs. 270); } \\
\text { anal cancer (156 vs. } 270) \text {; and } \\
\text { Hodgkin lymphoma (217 vs. 269), } \\
\text { compared to PWHIV without } \\
\text { cancer }\end{array}$ \\
\hline Clifford [30] & $\begin{array}{l}\text { Cohort study } \\
\text { (SHCS) }\end{array}$ & Switzerland & 2005 * & $\begin{array}{l}\text { - In PWHIV with CD4 count } \\
<100 \text { cells/ } \mu \mathrm{L} \text {, SIR was } 571 \\
\text { (95\% CI, 449-716) for KS and } 145 \\
\text { (104-197) for NHL. } \\
\text { SIR was } 25.7 \text { (95\% CI, 9.2-56.2) for } \\
\text { HL in PWHIV after AIDS } \\
\text { diagnosis and } 14.9 \text { (7.7-26.1) before } \\
\text { diagnosis. } \\
\text { For all NADC combined, SIRs } \\
\text { before and after AIDS diagnosis } \\
\text { were similar. }\end{array}$ \\
\hline
\end{tabular}

- In HIV-infected people with lower recent $\mathrm{CD} 4$ counts vs. non-infected people, there were higher RRs for KS $(p<0.001)$, NHL $(p<0.001)$, HL $(p<0.001)$, anal cancer $(p=0.005)$ and colorectal cancer $(p=0.028)$.

- $\quad$ RR in HIV-infected people with

$\begin{array}{lccr}\text { Silverberg [31] } & \begin{array}{c}\text { Cohort Study } \\ \text { (Kaiser) }\end{array} & \text { U.S.A. } & \text { 1996-2008 }\end{array}$
CD4 count $<200$ cells $/ \mu \mathrm{L}$ vs. noninfected people was $91.5(95 \%$ CI, 48.0-174.5) for anal cancer and 55.3 (31.3-97.9) for HL.

- $\quad$ For lung, colorectal and oral cavity/pharynx cancer, RRs were only elevated for HIV-infected individuals with CD4 count $<200$ cells $/ \mu \mathrm{L}$.

- Independent factors against the development of NADC include the use of triple cART compared to

$\begin{array}{lll}\text { Chiu [32] } & \begin{array}{c}\text { Cancer Registry (British } \\ \text { Columbia) }\end{array} & \text { Canada }\end{array}$
mono-/dual-ART (aOR, 0.64; 95\% CI, 0.43-0.95); and higher nadir CD4 counts (aOR, 0.61; 95\% CI, 0.41-0.93 for CD4 count $\geq 200$ cells $/ \mu \mathrm{L}$ ). 
Table 2. Cont.

\begin{tabular}{|c|c|c|c|c|}
\hline Reference & $\begin{array}{c}\text { Design } \\
\text { (Cohort Name) }\end{array}$ & Population & Study Period & $\begin{array}{c}\text { Impact of Advanced HIV Disease on } \\
\text { Cancer Incidence }\end{array}$ \\
\hline Kesselring [37] & $\begin{array}{l}\text { Cohort study } \\
\text { (ATHENA) }\end{array}$ & Netherlands & 1996-2009 & $\begin{array}{l}\text { Cumulative exposure to CD4 } \\
\text { count }<200 \text { cells } / \mu L \text { results in } \\
\text { higher risk of NADC (HR, } 1.12 ; \\
\text { range, } 1.03-1.22 \text { for each additional } \\
\text { year of exposure). } \\
\text { In stratified analyses, cumulative } \\
\text { exposure to CD4 count } \\
<200 \text { cells / } \mu \mathrm{L} \text { was associated with } \\
\text { malignancies caused by infections } \\
\text { (HR 1.16; range } 1.03-1.31 \text { ) but not } \\
\text { with other types of cancers. }\end{array}$ \\
\hline
\end{tabular}

- $\quad$ Factors associated with increased mortality for ADC are lower nadir CD4 counts and HIV $\mathrm{VL} \geq 400$ copies $/ \mathrm{mL}$, with respective HRs of $3.02(95 \%$

$\begin{array}{ccc}\text { Patel [35] } & \begin{array}{c}\text { Cohort Study } \\ (\text { HOS })\end{array} & \text { U.S.A. }\end{array}$ CI, 1.39-6.59) and 1.72 (1.01-2.94).

- Factors associated with increased mortality for NADCNI are lower nadir CD4 counts and detectable HIV VL, with respective HRs of 1.77 (95\% CI, 1.07-2.94) and 1.96 (1.18-3.24).

- $\quad$ Cancer incidence in patients with previous AIDS diagnosis compared with those with non-AIDS, expressed as SIR (95\% CI), was 8.02 (3.52-18.25) for leukemia, 2.77 (1.43-5.37) for HL, 3.01 (1.69-5.38) for lung cancer, and 3.17 (1.42-7.09) for all cancers combined.

- Adjusted RH for ADC and NADC, respectively, by $\mathrm{CD} 4$ count:
○ $\leq 50$ cells / $\mu$ L: 20.27 (95\% CI, 11.95-34.37; $p<0.001)$ and 2.44 (95\% CI, 0.76-7.83; $p=0.1$ )
50-200 cells/ $\mu \mathrm{L}: 6.48$ (95\%
CI, 3.98-10.57; $p<0.001$ and 2.76 (95\% CI, 1.35-5.65; $p=0,006)$ 200-350 cells/ $\mu \mathrm{L}: 1.73$ (95\% CI, 0.99-3.04; $p=0.054)$ and 1.69 (95\% CI, 0.9-3.2; $p=0.1)$

Prosperi [33]

Cohort study (ICONA)
2010 *

* Year of publication. ADC: AIDS-defining cancer; aOR: adjusted odds ratio; cART: combined antiretroviral therapy; CI: confidence interval; HL: Hodgkin lymphoma; HR: hazard ratio; KS: Kaposi sarcoma; NADC: non-AIDS-defining cancer; NADCNI: non-AIDS-defining noninfection-related cancer; NHL: non-Hodgkin lymphoma; PWHIV: people living with HIV; RR: relative risk; SIR: standardized incidence ratio; VL: viral load. 
Regarding mortality, Patel et al. [35] from the HIV Outpatient Study (HOPS) cohort reported that factors associated with all-cause mortality among persons with ADC were a nadir CD4 cell count $<200$ cells $/ \mathrm{mm}^{3}$ and HIV RNA $\geq 400$ copies $/ \mathrm{mL}$. Among persons with NADCI, no associated factors were identified. Among persons with NADC, factors associated with increased mortality were older age at cancer diagnosis, non-white race, nadir CD4 cell count $<200$ cells $/ \mathrm{mm}^{3}$, viral load $\geq 400$ copies $/ \mathrm{mL}$, and prior or current history of tobacco use.

\subsection{Cardiovascular Disease-Related Mortality in PWHIV with AHD}

The effect of AHD on the pathogenesis of cardiovascular disease (CVD) is not well established. Traditional cardiovascular risk factors seem to play the main role in this condition. However, some data suggest that AHD may influence the incidence and outcome of CVD and strokes. Authors from the NA-ACCORD cohort analyzed the incidence of type 1 (atherothrombotic) myocardial infarction (T1MI) and risk attributable to traditional and HIV-specific factors. The multivariable analysis showed that lower CD4 counts were significatively associated with higher risk T1MI. The adjusted incidence rate ratios (aIRR) for CD4 counts < 100 cells $/ \mu \mathrm{L}$ were: 2.19 (95\% CI: 1.44-3.33); 100-199 cells $/ \mu \mathrm{L}$ : 1.60 (95\% CI: 1.09-2.34); and 200-349 cells/ $\mu \mathrm{L}: 1.37$ (95\% CI: 1.01-1.86) [38]. In a systematic review and meta-analysis, Eyawo et al. [39] found that CD 4 count $<200$ cells $/ \mu \mathrm{L}$ was associated with higher MI risk compared with $\geq 200$ cells $/ \mu \mathrm{L}$ in three studies and HIV VL $\geq 100,000$ copies/mL was associated with increased MI risk compared with $<100,000$ copies/mL in two studies. However, Feinstein et al. reported that significant mortality predictors for T1MI in PWHIV were only high HIV viral load (HIV-VL), renal dysfunction, and older age; and for a type 2 (supply-demand mismatch) MI, low body-mass index and detectable HIV [40].

In a nationwide inpatient sample from the United States, PWHIV with previous AIDS were significantly more likely than uninfected patients to die during hospitalization after admission for MI (OR: 3.03; 95\% CI, 1.71-5.38), or stroke (OR: 2.59; 95\% CI, 1.97-3.4) [41]. In the same way, in a retrospective cohort study about the outcomes of MI and cardiogenic shock in PWHIV, AIDS was also associated with higher in-hospital mortality compared with HIV people without previous AIDS (28.8\% vs. 21.1\%; aOR: 4.12 [95\% CI: 1.89-9.00]) [42].

The authors of a Taiwanese study reported cytomegalovirus end-organ disease as an independent risk factor for incident all-cause stroke, and particularly ischemic stroke, in PWHIV [43]. Lastly, data from a meta-analysis including 724 cases of intracerebral hemorrhage linked AIDS diagnosis and low CD4 with higher incidence of this event [44].

All these data suggest the high vulnerability and risk of dying after an AHD diagnosis. Mortality related with NADEs could be prevented with the treatment of traditional risk factors such as smoking, elevated total cholesterol, hypertension, and chronic HCV infection [45]. Exhaustive screening of traditional risk factors is necessary to reduce mortality in PWHIV with previous or current AHD.

\subsection{AHD and Health-Related Quality of Life}

We reviewed 11 articles that analyzed the impact of AHD on HRQoL and that complied with the inclusion criteria (Table 3). These articles were heterogeneous, with different populations and different study designs. They used a variety in measurement tools, including generic and HIV-specific ones. Generic HRQOL measures are those applicable across types and severities of disease, across different medical treatments or health interventions, and demographic and cultural subgroups. Disease-specific measures are those that assess specific diagnosis groups or patient populations such as PWHIV. Six of the reviewed articles were cross-sectional studies, and five had a longitudinal design. All studies were conducted in high-income countries, mostly in North America. Sample sizes ranged from 744 to 2508 PWHIV in the cross-sectional studies, and from 265 to 1000 PWHIV in the longitudinal studies. 
All the studies found an association between CD4 count and HRQoL. Some associated low CD4 counts with lower overall HRQoL scores or self-perception of health [46-48], while others linked low CD4 count to worse physical health status [49] or mental health status [50,51]. A cross-sectional study using a multidimensional HIV-specific HRQoL measure showed that PWHIV with the lowest CD4 counts had the lowest scores in several HRQoL domains, including physical health status [48]. Longitudinal studies found that lower CD4 count predicted worse physical health status and worse mental health status [52-56].

Some cross-sectional studies $[50,51]$ and longitudinal studies $[52,54,56]$ found that AIDS defining events impaired HRQoL.

Some studies associate worse HRQoL with other variables that are potentially related to HIV disease progression, such as HCV coinfection [46], cART adverse events [50-52,54] and medical comorbidities (including HIV-related symptoms and non-AIDS comorbidities) $[49,55,56]$.

In addition to clinical and biological markers, the studies we reviewed consistently associated several socio-demographic and psychosocial factors with worse HRQoL in PWHIV. These factors included ageing, housing, depression, social support, employment, and HIV-related stigma.

Table 3. Impact of advanced HIV disease on health-related quality of life. Cross-sectional and longitudinal studies.

\begin{tabular}{|c|c|c|c|c|c|c|}
\hline $\begin{array}{c}\text { Reference } \\
\text { (Cohort Name) }\end{array}$ & $\begin{array}{l}\text { No. Patients } \\
\text { (Age in Years) }\end{array}$ & Location & Study Period & $\begin{array}{c}\text { HRQoL } \\
\text { Questionnaires }\end{array}$ & $\begin{array}{l}\text { Impact of Advanced } \\
\text { HIV Disease on HRQoL }\end{array}$ & $\begin{array}{c}\text { Other Factors } \\
\text { Associated with HRQoL }\end{array}$ \\
\hline \multicolumn{7}{|c|}{ Cross-sectional studies } \\
\hline $\begin{array}{l}\text { Aden [46] } \\
\text { (WHIS) }\end{array}$ & $\begin{array}{c}n=2508 \\
\text { (Not reported) }\end{array}$ & U.S.A. & 1994-2006 & SF-6D & $\begin{array}{l}\text { Women with HIV } \\
\text { with CD } 4 \text { count } \leq \\
200 \text { cells } / \mu \mathrm{L}^{2} \text { had } \\
\text { lower mean } \\
\text { HRQoL scores than } \\
\text { women with HIV } \\
\text { with CD }>200 \\
\text { cells } / \mu \mathrm{L} \text { and } \\
\text { women without } \\
\text { HIV ( } p<0.01) . \\
\text { Women with HIV } \\
\text { with detectable } \\
\text { viral load had } \\
\text { lower HRQoL } \\
\text { scores than those } \\
\text { with undetectable } \\
\text { viral load ( } p<0.01) \text {. } \\
\text { In the multivariate } \\
\text { analysis, chronic } \\
\text { HCV ( } p<0.01), \text { and } \\
\text { low CD4 count }(p< \\
0.01) \text { were } \\
\text { independently } \\
\text { associated with } \\
\text { lower HRQoL }\end{array}$ & $\begin{array}{l}\text { - } \\
\text { declined with } \\
\text { increasing age and } \\
\text { decreasing level of } \\
\text { education. } \\
\text { Current use of } \\
\text { illicit drugs was } \\
\text { associated with } \\
\text { lower HRQoL } \\
\text { scores }\end{array}$ \\
\hline
\end{tabular}


Table 3. Cont.

\begin{tabular}{|c|c|c|c|c|c|c|}
\hline $\begin{array}{c}\text { Reference } \\
\text { (Cohort Name) }\end{array}$ & $\begin{array}{l}\text { No. Patients } \\
\text { (Age in Years) }\end{array}$ & Location & Study Period & $\begin{array}{c}\text { HRQoL } \\
\text { Questionnaires }\end{array}$ & $\begin{array}{l}\text { Impact of Advanced } \\
\text { HIV Disease on HRQoL }\end{array}$ & $\begin{array}{c}\text { Other Factors } \\
\text { Associated with HRQoL }\end{array}$ \\
\hline \multicolumn{7}{|c|}{ Cross-sectional studies } \\
\hline $\begin{array}{l}\text { Preau [50] } \\
\text { (ANRS) }\end{array}$ & $\begin{array}{c}n=2235 \\
\text { (mean, } 42.5 ; \mathrm{SD}, \\
9.4)\end{array}$ & France & 2003 & MOS SF-36 & $\begin{array}{l}\text { Detectable HIV-VL } \\
2(p=0.02), \\
\text { AIDS-defining } \\
\text { events }(p=0.003) \\
\text { and adverse HIV } \\
\text { treatment reactions } \\
(p<0.0001) \text { were } \\
\text { associated with low } \\
\text { PHS. } \\
\text { Low CD } 4 \text { cell } \\
\text { count }{ }^{2}(p=0.0007) \\
\text { and adverse HIV } \\
\text { treatment reactions } \\
(p<0.0001) \text { were } \\
\text { associated with low } \\
\text { MHS. }\end{array}$ & 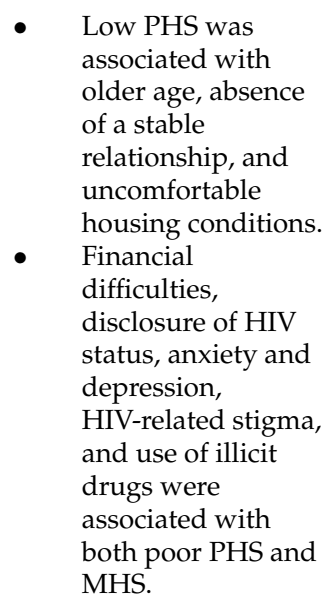 \\
\hline Fumaz [51] & $\begin{array}{c}n=744 \\
\text { (median, 44; } \\
\text { IQR, 37-48) }\end{array}$ & Spain & 2010-2011 & MOS-HIV & $\begin{array}{l}\text { Variables } \\
\text { associated with } \\
\text { PHS in men were } \\
\text { absence of SAEs }(p \\
<0.01) \text { and past OI } \\
(p<0.01) \text {; and in } \\
\text { women, years since } \\
\text { HIV diagnosis }(p< \\
0.01), \text { absence of } \\
\text { SAEs }(p<0.01), \\
\text { and past OI ( } p< \\
0.01) . \\
\text { Better MHS was } \\
\text { related to higher } \\
\text { CD4 count }{ }^{1}(p= \\
0.02) \text { and absence } \\
\text { of SAEs }(p=0.04) \\
\text { in women with } \\
\text { HIV. Men and } \\
\text { women coincided } \\
\text { in the absence of } \\
\text { past OI being } \\
\text { related to better } \\
\text { MHS }(p<0.01) .\end{array}$ & $\begin{array}{l}\text { Employment and } \\
\text { HIV not acquired } \\
\text { through the } \\
\text { injection route was } \\
\text { related to better } \\
\text { PHS and MHS in } \\
\text { men with HIV. } \\
\text { Having a stable } \\
\text { partner was related } \\
\text { only to better MHS } \\
\text { in men. }\end{array}$ \\
\hline $\begin{array}{l}\text { Emuren [49] } \\
\text { (NHS) }\end{array}$ & $\begin{array}{c}n=1668 \\
\text { (median, 40; } \\
\text { IQR, 32.0-47.0) }\end{array}$ & U.S.A. & 2006-2010 & SF-36 & $\begin{array}{l}\text { - } \mathrm{CD} 4 \text { count }<200 \\
\text { cells } / \mu \mathrm{L}^{2}(p< \\
0.0001), \mathrm{AIDS} \\
\text { diagnosis }(p= \\
0.0009), \text { and } \\
\text { medical } \\
\text { comorbidities }(p< \\
0.0001) \text { were } \\
\text { associated with } \\
\text { lower PHS. } \\
\text { CD4 count }<200 \\
\text { cells } / \mu \mathrm{L}^{2}(p<0.05) \\
\text { was associated } \\
\text { with lower MHS. }\end{array}$ & 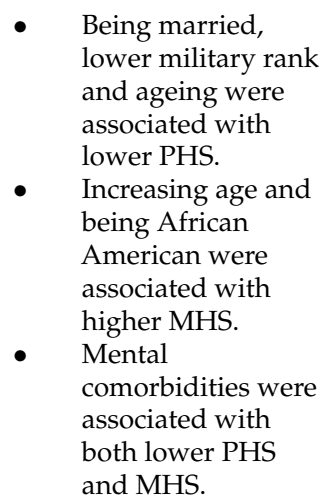 \\
\hline
\end{tabular}


Table 3. Cont.

\begin{tabular}{|c|c|c|c|c|c|c|}
\hline $\begin{array}{c}\text { Reference } \\
\text { (Cohort Name) }\end{array}$ & $\begin{array}{l}\text { No. Patients } \\
\text { (Age in Years) }\end{array}$ & Location & Study Period & $\begin{array}{c}\text { HRQoL } \\
\text { Questionnaires }\end{array}$ & $\begin{array}{l}\text { Impact of Advanced } \\
\text { HIV Disease on HRQoL }\end{array}$ & $\begin{array}{c}\text { Other Factors } \\
\text { Associated with HRQoL }\end{array}$ \\
\hline \multicolumn{7}{|c|}{ Cross-sectional studies } \\
\hline Fuster [48] & $\begin{array}{c}n=1462 \\
\text { (mean, 45.0; SD, } \\
10.2 \text { ) }\end{array}$ & Spain & 2016-2017 & $\begin{array}{l}\text { WHOQOL-HIV- } \\
\text { BREF }\end{array}$ & $\begin{array}{l}\text { Participants with } \\
\text { CD4 count }<200 \\
\text { cells } / \mu \mathrm{L}^{1} \text { had the } \\
\text { lowest scores in the } \\
\text { following } \\
\text { dimensions of } \\
\text { HRQoL: general } \\
\text { health }(p<0.0001) \text {, } \\
\text { physical health }(p= \\
\text { 0.004), level of } \\
\text { independence ( } p< \\
\text { 0.0001) and } \\
\text { environmental } \\
\text { health }(p=0.005) .\end{array}$ & $\begin{array}{l}\text { Being female, being } \\
\text { heterosexual, } \\
\text { having low } \\
\text { socioeconomic and } \\
\text { educational status, } \\
\text { having acquired } \\
\text { HIV through an } \\
\text { injection route, and } \\
\text { living more years } \\
\text { with HIV were } \\
\text { related to poorer } \\
\text { HRQoL. }\end{array}$ \\
\hline Venturini [47] & $\begin{array}{c}n=943 \\
\text { (mean, 50.9; SD, } \\
\text { 9.3) }\end{array}$ & Italy & 2015 & $\begin{array}{l}\text { EQ-5D-3L } \\
\text { EQ-VAS }\end{array}$ & $\begin{array}{l}\text { Patients with CD4 } \\
\text { count }<200 \\
\text { cells } / \mu \mathrm{L}^{2} \\
\text { compared with }> \\
500 \text { cells } / \mu \mathrm{L} \text { had a } \\
\text { lower score in the } \\
\text { EQ-VAS }(p=0.02)\end{array}$ & $\begin{array}{l}\text { Older age, HCV } \\
\text { coinfection, } \\
\text { education level and } \\
\text { hospitalization due } \\
\text { to HIV were } \\
\text { associated with a } \\
\text { low perception of } \\
\text { health (EQ-VAS). }\end{array}$ \\
\hline
\end{tabular}

$\begin{array}{cccc}\begin{array}{c}\text { Protopopescu } \\ \text { [52] }\end{array} & n=1000 & & \\ \text { (mean, 37.1; SD, } & \text { France } & 1997-2000 & \text { MOS SF-36 }\end{array}$

- $\quad$ CD4 deficiency and number of self-reported side effects were negatively associated with PHS $(p<0.0001$ for both variables in both random and joint effect models) and MHS ( $p=0.021$ in random effect model and $p=$ 0.018 in the joint model for CD4 count and $p<$ 0.0001 in both models for side effects) over 5 years after HAART initiation.

- Clinical stage of AIDS $(p<0.0001$ for both random effects and joint model and $\mathrm{HCV}$ coinfection were negative predictors of PHS ( $p=0.047$ for both models).

- $\quad$ Low age, high education level and being MSM were associated with better PHS.

- Having a stable partner and HIV infection not acquired through the injection route were associated with higher MHS.

Comfortable housing conditions were positively associated with PHS and MHS. 
Table 3. Cont.

\begin{tabular}{|c|c|c|c|c|c|c|}
\hline $\begin{array}{c}\text { Reference } \\
\text { (Cohort Name) }\end{array}$ & $\begin{array}{l}\text { No. Patients } \\
\text { (Age in Years) }\end{array}$ & Location & Study Period & $\begin{array}{c}\text { HRQoL } \\
\text { Questionnaires }\end{array}$ & $\begin{array}{l}\text { Impact of Advanced } \\
\text { HIV Disease on HRQoL }\end{array}$ & $\begin{array}{l}\text { Other Factors } \\
\text { Associated with HRQoL }\end{array}$ \\
\hline \multicolumn{7}{|c|}{ Cross-sectional studies } \\
\hline $\begin{array}{l}\text { Nieuwkerk [53] } \\
\text { (ATHENA) }\end{array}$ & $\begin{array}{c}n=265 \\
\text { (mean, } 40.1 ; \mathrm{SD}, \\
8.7)\end{array}$ & Netherlands & 1998-2005 & MOS-HIV & $\begin{array}{l}\text { Patients who } \\
\text { started HAART } \\
\text { with }<200 \text { CD4 } \\
\text { cells } / \mu L^{2} \text { had } \\
\text { significantly worse } \\
\text { baseline PHS than } \\
\text { those who started } \\
\text { with }>200 \text { CD } 4 \\
\text { cells } / \mu \mathrm{L} \text {. } \\
\text { These patients } \\
\text { showed a } \\
\text { significantly } \\
\text { greater } \\
\text { improvement in } \\
\text { PHS than those } \\
\text { who started } \\
\text { HAART with } \\
\text { higher CD4 count } \\
\text { ( }>200 \text { cells } / \mu \mathrm{L})\end{array}$ & \\
\hline $\begin{array}{c}\text { Anis [54] } \\
\text { (OPTIMA } \\
\text { clinical trial) }\end{array}$ & $\begin{array}{c}n=368 \\
\text { (mean, } 48.0 ; \mathrm{SD} \\
8.5)\end{array}$ & $\begin{array}{l}\text { U.S.A., } \\
\text { U.K., } \\
\text { Canada }\end{array}$ & 2001-2007 & $\begin{array}{l}\text { MOS-HIV, } \\
\text { EQ-5D }\end{array}$ & $\begin{array}{l}\text { ADEs and SAEs }{ }^{2} \\
\text { had significant } \\
\text { negative impacts } \\
\text { on HRQoL in the } \\
\text { multivariate linear } \\
\text { regression model. } \\
\text { ADEs had a more } \\
\text { persistent effect on } \\
\text { HRQoL than SAEs, } \\
\text { with a larger } \\
\text { magnitude of effect } \\
\text { across all } \\
\text { instruments. } \\
\text { Increasing CD4 } \\
\text { count was } \\
\text { significantly } \\
\text { associated with } \\
\text { increasing HRQoL } \\
\text { scores ( } p<0.01 \text { for } \\
\text { PHS and MHS). } \\
\text { Improvements in } \\
\text { HIV-VL had } \\
\text { significant positive } \\
\text { impacts on HRQoL, } \\
\text { although the } \\
\text { magnitude was } \\
\text { smaller than that of } \\
\text { CD4 increase }(p< \\
0.05 \text { for PHS, } p< \\
0.01 \text { for MHS). }\end{array}$ & \\
\hline
\end{tabular}


Table 3. Cont.

\begin{tabular}{|c|c|c|c|c|c|c|}
\hline $\begin{array}{c}\text { Reference } \\
\text { (Cohort Name) }\end{array}$ & $\begin{array}{l}\text { No. Patients } \\
\text { (Age in Years) }\end{array}$ & Location & Study Period & $\begin{array}{c}\text { HRQoL } \\
\text { Questionnaires }\end{array}$ & $\begin{array}{l}\text { Impact of Advanced } \\
\text { HIV Disease on HRQoL }\end{array}$ & $\begin{array}{c}\text { Other Factors } \\
\text { Associated with HRQoL }\end{array}$ \\
\hline \multicolumn{7}{|c|}{ Cross-sectional studies } \\
\hline $\begin{array}{l}\text { Liu [55] } \\
\text { (MACS) }\end{array}$ & $\begin{array}{c}n=636 \\
\text { (median, 43.3; } \\
\text { IQR, 39.0-48.2) }\end{array}$ & U.S.A. & 2001-2004 & SF-36 & $\begin{array}{l}\text { - } \\
\text { indicators of worse } \\
\text { PHS were lower } \\
\text { CD4 counts }{ }^{2} \text {, } \\
\text { taking OI } \\
\text { medications }(p< \\
0.05) \text {, increasing } \\
\text { number of } \\
\text { HIV-related } \\
\text { symptoms ( } p< \\
0.0001) \text { and } \\
\text { non-AIDS } \\
\text { comorbidities ( } p< \\
0.0001) . \\
\text { An AIDS diagnosis } \\
\text { by itself was no } \\
\text { longer significantly } \\
\text { related to PHS after } \\
\text { controlling for } \\
\text { variables such as } \\
\text { HIV symptoms } \\
\text { and the current use } \\
\text { of OI medications. }\end{array}$ & $\begin{array}{l}\text { Older age, lower } \\
\text { socioeconomic } \\
\text { status, fewer male } \\
\text { sexual partners, } \\
\text { and no alcohol } \\
\text { drinking were } \\
\text { significant } \\
\text { predictors of lower } \\
\text { PHS scores. } \\
\text { Use of recreational } \\
\text { drugs, interruption } \\
\text { of ART in the past } \\
\text { six months, and } \\
\text { low social support } \\
\text { were significant } \\
\text { predictors of poor } \\
\text { MHS. }\end{array}$ \\
\hline Emuren [56] & $\begin{array}{c}n=812 \\
(\text { median, 42; } \\
\text { IQR, 37.0-47.0) }\end{array}$ & U.S.A. & 2006-2010 & SF-36 & $\begin{array}{l}\text { CD4 count }<200 \\
\text { cells } / \mu \mathrm{L}^{2} \\
\text { predicted both PHS } \\
(p=0.0008) \text { and } \\
\text { MHS }(p=0.0003) . \\
\text { Medical } \\
\text { comorbidities }(p< \\
0.0001), \text { and ADE } \\
(p<0.0001) \text { were } \\
\text { also significant } \\
\text { predictors of PHS. } \\
\text { Patients with } \\
\text { medical } \\
\text { comorbidities } \\
\text { experienced a } \\
\text { yearly } \\
\text { improvement in } \\
\text { PHS. }\end{array}$ & $\begin{array}{l}\text { - } \\
\text { longing led to a } \\
\text { reduction in PHS. } \\
\text { Mental } \\
\text { comorbidities were } \\
\text { associated with } \\
\text { both PHS and } \\
\text { MHS. }\end{array}$ \\
\hline
\end{tabular}

ADE: AIDS-defining event; EQ-5D: EuroQol 5-dimension quality of life instrument; EQ-5D-3L: EuroQol 5-dimension-3-level quality of life instrument; HAART: highly active antiretroviral therapy; HCV: hepatitis C virus; HIV-VL: HIV viral load; HRQoL: health-related quality of life; MHS: mental health status; MOS-HIV-30: Medical Outcomes Study HIV Health Survey; MSM: men who have sex with men; OI: opportunistic infections; PHS: physical health status; SAE: serious adverse event; SD: standard deviation; SF-12: 12-Item Short-Form Health Survey; SF-36: 36-Item Short Form Health Survey; SF-6D: 6-Dimension Short Form Health Survey; VAS: visual analogue scale; WHOQOL-HIV-BREF: World Health Organization quality of life survey for HIV patients. Source of biological markers (CD4 cell count, viral load): ${ }^{1}$ patient self-reported, ${ }^{2}$ clinical records.

\section{Discussion and Conclusions}

Despite the efficacy and safety of current cART, PWHIV presenting for care with AHD or who progress to AIDS are at higher risk of mortality by new ADEs or NADEs. Longitudinal cohort studies and meta-analyses performed during the cART era demonstrate that AHD is associated with a higher risk of developing ADC and NADC, especially NADCI. Traditional cardiovascular risk factors, exposure to some antiretroviral drugs, and persistent HIV viremia are associated with CVD in PWHIV. However, data from cohort studies suggest that AHD could be associated with stroke, CVD, and related mortality. Patients with previous cytomegalovirus end-organ disease or lower nadir CD4 are at risk of 
developing ischemic strokes. AHD also leads to worse HRQoL. Most of the studies about HRQoL presented in this review are cross-sectional studies. Unfortunately, longitudinal studies evaluating the quality of life in patients previously diagnosed with AHD are scarce. Of those presented in this review, most include a large number of patients, strengthening the results. These studies agree that lower CD4 and previous AIDS diagnosis are associated with lower HRQoL scores, regardless of the questionnaire used or other known variables associated with worse HRQoL. We need more longitudinal studies that analyze the HRQoL for longer periods of time after an AHD diagnosis.

Antiretroviral Treatment guidelines from the World Health Organization (WHO) [57] and from the British HIV Association (BHIVA) [58] consider the AHD as a special issue, but both guidelines focus their interest on the treatment and prevention of opportunist diseases. Our study highlights the need to define AHD as a special state in the spectrum of HIV disease. The high incidence of NADEs and mortality found in AHD patients could be lowered with interventions on traditional risk factors; hence, the importance of screening for risk factors, improving prevention, and creating sustainable care models to implement these interventions during follow-up. We need more longitudinal studies that analyze the HRQoL for longer periods of time after an AHD diagnosis. In our opinion, HIV guidelines should consider AHD patients as a special population whose needs are different from PWHIV who present for care soon after HIV infection.

Author Contributions: J.P.-T., M.J.F.R.-d.-A. and J.P. designed the study and contributed to methodology and conceptualizations; J.P.-T., M.J.F.R.-d.-A. and J.P. to data curation; J.P.-T., S.R., I.P., M.J.F.R.-d.A. and J.P. contributed to writing, review and editing. S.R., I.P. and J.P. supervised de final manuscript. All authors have read and agreed to the published version of the manuscript.

Funding: This research received no external funding.

Institutional Review Board Statement: Not applicable.

Informed Consent Statement: Not applicable.

Data Availability Statement: Not applicable.

Conflicts of Interest: The authors declare no conflict of interest.

\section{References}

1. Volberding, P.A. How to Survive a Plague: The Next Great HIV/AIDS History. JAMA 2017, 317, 1298-1299. [CrossRef]

2. Krentz, H.B.; Gill, M.J. Long-term HIV/AIDS survivors: Patients living with HIV infection retained in care for over 20 years. What have we learned? Int. J. STD AIDS 2018, 29, 1098-1105. [CrossRef]

3. Buscher, A.L.; Giordano, T. Gaps in Knowledge in Caring for HIV Survivors Long-term. JAMA 2010, 304, 340-341. [CrossRef]

4. Detels, R.; Jacobson, L.; Margolick, J.; Martinez-Maza, O.; Muñoz, A.; Phair, J.; Rinaldo, C.; Wolinsky, S. The multicenter AIDS Cohort Study, 1983 to ... . Public Health 2012, 126, 196-198. [CrossRef]

5. World Health Organization. UNAIDS. 2019. Available online: http://aidsinfo.unaids.org/ (accessed on 11 February 2021).

6. European Centre for Disease Prevention and Control. HIV Infection and AIDS. In: ECDC. Annual Epidemiological Report for 2017. Stockholm. 2019. Available online: https:/ / www.ecdc.europa.eu/sites/default/files/documents/hiv-infection-aids-annual-epidemiological-report-2017.pdf (accessed on 11 February 2021).

7. Calmy, A.; Ford, N.; Meintjes, G. The Persistent Challenge of Advanced HIV Disease and AIDS in the Era of Antiretroviral Therapy. Clin. Infect. Dis. 2018, 66 (Suppl. 2), S103-SS105. [CrossRef]

8. Centers for Disease Control and Prevention (CDC). Revised surveillance case definition for HIV infection-United States, 2014. MMWR Recomm. Rep. 2014, 63, 1-10.

9. Mocroft, A.; Lundgren, J.; Antinori, A.; Monforte, A.; Brännström, J.; Bonnet, F.; Brockmeyer, N.; Casabona, J.; Castagna, A.; Costagliola, D.; et al. Late presentation for HIV care across Europe: Update from the Collaboration of Observational HIV Epidemiological Research Europe (COHERE) study, 2010 to 2013. Euro. Surveill. 2015, 20. [CrossRef]

10. Raffetti, E.; Concetta-Postorino, M.; Castelli, F.; Casari, S.; Castelnuovo, F.; Maggiolo, F.; Di Filippo, E.; D’Avino, A.; Gori, A.; Ladisa, N.; et al. The risk of late or advanced presentation of HIV infected patients is still high, associated factors evolve but impact on overall mortality is vanishing over calendar years: Results from the Italian MASTER Cohort. BMC Public Health 2016, 16, 878. [CrossRef]

11. Tanser, F.; Bärnighausen, T.; Vandormael, A.; Dobra, A. HIV treatment cascade in migrants and mobile populations. Curr. Opin. HIV AIDS 2015, 10, 430-438. [CrossRef] 
12. Milloy, M.J.; Marshall, B.D.; Kerr, T.; Buxton, J.; Rhodes, T.; Montaner, J.; Wood, E. Social and structural factors associated with HIV disease progression among illicit drug users: A systematic review. AIDS 2012, 26, 1049-1063. [CrossRef]

13. Peng, G.; Rapkin, J.; Krason, D.; Reilly, C.; Cavert, W.P.; Abrams, D.I.; MacArthur, R.D.; Henry, K.; Neadon, J.D. Poor initial CD4+ recovery with antiretroviral therapy prolongs immune depletion and increases risk for AIDS and non-AIDS diseases. J. Acquir. Immune Defic. Syndr. 2008, 48, 541-546. [CrossRef]

14. Kelly, C.; Gaskell, K.M.; Richardson, M.; Klein, N.; Garner, P.; MacPherson, P. Discordant Immune Response with Antiretroviral Therapy in HIV-1, a Systematic Review of Clinical Outcomes. PLoS ONE 2016, 11, e0156099. [CrossRef]

15. Fontela, C.; Aguinaga, A.; Moreno-Iribas, C.; Repáraz, J.; Rivero, M.; Gracia, M.; Floristán, Y.; Fresán, U.; San Miguel, R.; Expeleta, C.; et al. Trends and causes of mortality in a population-based cohort of HIV-infected adults in Spain: Comparison with the general population. Sci. Rep. 2020, 10, 8922. [CrossRef] [PubMed]

16. Hogg, R.; Lima, V.; Sterne, J.A.; Grabar, S.; Battegay, M.; Bonarek, M.; Monforte, D.A.; Esteve, A.; Gill, M.J.; Harris, R.; et al. Life expectancy of individuals on combination antiretroviral therapy in high-income countries: A collaborative analysis of 14 cohort studies. Lancet 2008, 372, 293-299. [CrossRef]

17. Losina, E.; Schackman, B.R.; Sadownik, S.N.; Gebo, K.A.; Walensky, R.P.; Chiosi, J.J.; Weinstein, M.C.; Hicks, P.L.; Aaronson, W.H.; Moore, R.D.; et al. Racial and sex disparities in life expectancy losses among HIV-infected persons in the United States: Impact of risk behavior, late initiation, and early discontinuation of antiretroviral therapy. Clin. Infect. Dis. 2009, 49, 1570-1578. [CrossRef]

18. May, M.T.; Gompels, M.; Delpech, V.; Porter, K.; Orkin, C.; Kegg, S.; Hay, P.; Johnson, M.; Palfreeman, A.; Gilson, R.; et al. Impact on life expectancy of HIV-1 positive individuals of CD4+ cell count and viral load response to antiretroviral therapy. AIDS 2014, 28, 1193-1202. [CrossRef]

19. Zhang, S.; van Sighem, A.; Kesselring, A.; Gras, L.; Prins, J.M.; Hassink, E.; Kauffman, R.; Richter, C.; Wolf, F.; Reiss, P.; et al. Athena national observational HIV cohort study. Risk of non-AIDS-defining events among HIV-infected patients not yet on antiretroviral therapy. HIV Med. 2015, 16, 265-272. [CrossRef]

20. Sobrino-Vegas, P.; Moreno, S.; Rubio, R.; Viciana, P.; Bernardino, J.I.; Blanco, J.R.; Bernal, E.; Asensi, V.; Pulido, F.; del Amo, J.; et al. Impact of late presentation of HIV infection on short-, mid- and long-term mortality and causes of death in a multicenter national cohort: 2004-2013. J. Infect. 2016, 72, 587-596. [CrossRef]

21. Pettit, A.C.; Giganti, M.J.; Ingle, S.M.; May, M.T.; Shepherd, B.E.; Gill, M.J.; Fatkenheuer, G.; Abgrall, S.; Saag, M.S.; Del Amo, J.; et al. Increased non-AIDS mortality among persons with AIDS-defining events after antiretroviral therapy initiation. J. Int. AIDS Soc. 2018, 21, e25031. [CrossRef]

22. Ingle, S.M.; May, M.T.; Gill, M.J.; Mugavero, M.J.; Lewden, C.; Abgrall, S.; Fatkenheuer, G.; Reiss, P.; Saag, M.S.; Manzardo, C.; et al. Impact of risk factors for specific causes of death in the first and subsequent years of antiretroviral therapy among HIV-infected patients. Clin. Infect. Dis. 2014, 59, 287-297. [CrossRef]

23. Mocroft, A.; Lundgren, J.D.; Sabin, M.L.; Monforte, A.D.; Brockmeyer, N.; Casabona, J.; Castagna, A.; Costagliola, D.; Dabis, F.; De Wit, S.; et al. Risk factors and outcomes for late presentation for HIV-positive persons in Europe: Results from the Collaboration of Observational HIV Epidemiological Research Europe Study (COHERE). PLoS Med. 2013, 10, e1001510. [CrossRef]

24. Montlahuc, C.; Guiguet, M.; Abgrall, S.; Daneluzzi, V.; de Salvador, F.; Launay, O.; Martinez, V.; Partisani, M.; Pradier, C.; Rouveix, E.; et al. Impact of late presentation on the risk of death among HIV-infected people in France (2003-2009). J. Acquir. Immune Defic. Syndr. 2013, 64, 197-203. [CrossRef] [PubMed]

25. May, M.T.; Vehreschild, J.J.; Trickey, A.; Obel, N.; Reiss, P.; Bonnet, F.; Mary-Krause, M.; Samji, H.; Cavassini, M.; John Gill, M.J.; et al. Mortality According to CD4 Count at Start of Combination Antiretroviral Therapy Among HIV-infected Patients Followed for up to 15 Years After Start of Treatment: Collaborative Cohort Study. Clin. Infect. Dis. 2016, 62, 1571-1577. [CrossRef]

26. Baker, J.V.; Peng, G.; Rapkin, J.; Abrams, D.I.; Silverberg, M.J.; MacArthur, R.D.; Cavert, W.P.; Henry, W.K.; Neaton, J.D.; Terry Beirn Community Programs for Clinical Research on AIDS (CPCRA). CD4+ count and risk of non-AIDS diseases following initial treatment for HIV infection. AIDS 2008, 22, 841-848. [CrossRef]

27. Marin, B.; Thiébaut, R.; Bucher, H.C.; Rondeau, V.; Costagliola, D.; Dorrucci, M.; Hamouda, O.; Prins, M.; Walker, S.; Porter, K.; et al. Non-AIDS-defining deaths and immunodeficiency in the era of combination antiretroviral therapy. AIDS 2009, 23, 1743-1753. [CrossRef]

28. Mocroft, A.; Reiss, P.; Gasiorowski, J.; Ledergerber, B.; Kowalska, J.; Chiesi, A.; Gatell, J.; Rakhmanova, A.; Johnson, M.; Kirk, O.; et al. Serious fatal and nonfatal non-AIDS-defining illnesses in Europe. J. Acquir. Immune Defic. Syndr. 2010, 55, 262-270. [CrossRef] [PubMed]

29. Young, J.; Psichogiou, M.; Meyer, L.; Ayayi, S.; Grabar, S.; Raffi, F.; Reiss, P.; Gazzard, B.; Sharland, M.; Gutiérrez, F.; et al. CD4 cell count and the risk of AIDS or death in HIV-Infected adults on combination antiretroviral therapy with a suppressed viral load: A longitudinal cohort study from COHERE. PLoS Med. 2012, 9, e1001194. [CrossRef]

30. Clifford, G.M.; Polesel, J.; Rickenbach, M.; Dal Maso, L.; Keiser, O.; Kofler, A.; Rapiti, E.; Levi, F.; Jundt, G.; Fisch, T.; et al. Cancer risk in the Swiss HIV Cohort Study: Associations with immunodeficiency, smoking, and highly active antiretroviral therapy. J. Natl. Cancer Inst. 2005, 97, 425-432. [CrossRef]

31. Silverberg, M.J.; Chao, C.; Leyden, W.A.; Xu, L.; Horberg, M.A.; Klein, D.; Towner, W.J.; Dubrow, R.; Quesenberry, C.P.; Neugebauer, R.S.; et al. HIV infection, immunodeficiency, viral replication, and the risk of cancer. Cancer Epidemiol. Biomarkers Prev. 2011, 20, 2551-2559. [CrossRef] 
32. Chiu, C.G.; Smith, D.; Salters, K.A.; Zhang, W.; Kanters, S.; Milan, D.; Montaner, J.; Coldman, A.; Hogg, R.S.; Wiseman, S.M. Overview of cancer incidence and mortality among people living with HIV/AIDS in British Columbia, Canada: Implications for HAART use and NADM development. BMC Cancer 2017, 17, 270. [CrossRef] [PubMed]

33. Prosperi, M.C.; Cozzi-Lepri, A.; Castagna, A.; Mussini, C.; Murri, R.; Giacometti, A.; Torti, C.; Costantini, A.; Narciso, P.; Ghinelli, F.; et al. Incidence of malignancies in HIV-infected patients and prognostic role of current CD4 cell count: Evidence from a large Italian cohort study. Clin. Infect. Dis. 2010, 50, 1316-1321. [CrossRef]

34. Bedimo, R.J.; McGinnis, K.A.; Dunlap, M.; Rodriguez-Barradas, M.C.; Justice, A.C. Incidence of non-AIDS-defining malignancies in HIV-infected versus noninfected patients in the HAART era: Impact of immunosuppression. J. Acquir. Immune Defic. Syndr. 2009, 52, 203-208. [CrossRef]

35. Patel, P.; Armon, C.; Chmiel, J.S.; Brooks, J.T.; Buchacz, K.; Wood, K.; Novak, R.M. Factors associated with cancer incidence and with all-cause mortality after cancer diagnosis among human immunodeficiency virus-infected persons during the combination antiretroviral therapy era. Open Forum. Infect. Dis. 2014, 1, ofu012. [CrossRef]

36. Shiels, M.S.; Cole, S.R.; Kirk, G.D.; Poole, C. A meta-analysis of the incidence of non-AIDS cancers in HIV-infected individuals. J. Acquir. Immune Defic. Syndr. 2009, 52, 611-622. [CrossRef]

37. Kesselring, A.; Gras, L.; Smit, C.; van Twillert, G.; Verbon, A.; de Wolf, F.; Reiss, P.; Wit, F. Immunodeficiency as a risk factor for non-AIDS-defining malignancies in HIV-1-infected patients receiving combination antiretroviral therapy. Clin. Infect. Dis. 2011, 52, 1458-1465. [CrossRef]

38. Drozd, D.R.; Kitahata, M.M.; Althoff, K.N.; Zhang, J.; Gange, S.J.; Napravnik, S.; Burkholder, G.A.; Mathews, W.C.; Silverberg, M.J.; Sterling, T.R.; et al. Increased Risk of Myocardial Infarction in HIV-Infected Individuals in North America Compared with the General Population. J. Acquir. Immune Defic. Syndr. 2017, 75, 568-576. [CrossRef]

39. Eyawo, O.; Brockman, G.; Goldsmith, C.H.; Hull, M.W.; Lear, S.A.; Bennett, M.; Guillemi, S.; Franco-Villalobos, C.; Adam, A.; Mills, E.J.; et al. Risk of myocardial infarction among people living with HIV: An updated systematic review and meta-analysis. BMJ Open 2019, 9, e025874. [CrossRef]

40. Feinstein, M.J.; Nance, R.M.; Delaney, J.A.C.; Heckbert, S.R.; Budoff, M.J.; Drozd, D.R. Mortality following myocardial infarction among HIV-infected persons: The Center for AIDS Research Network of Integrated Clinical Systems (CNICS). BMC Med. 2019, 17, 149. [CrossRef]

41. Okeke, N.L.; Hicks, C.B.; McKellar, M.S.; Fowler, V.G., Jr.; Federspiel, J.J. History of AIDS in HIV-Infected Patients Is Associated with Higher In-Hospital Mortality Following Admission for Acute Myocardial Infarction and Stroke. J. Infect. Dis. 2016, 213, 1955-1961. [CrossRef]

42. Vallabhajosyula, S.; Subramaniam, A.V.; Sundaragiri, P.R.; Cheungpasitporn, W.; Temesgen, Z.; O’Horo, J.C.; Jaffe, A.S.; Barsness, G.W. Influence of Human Immunodeficiency Virus Infection on the Management and Outcomes of Acute Myocardial Infarction with Cardiogenic Shock. J. Acquir. Immune Defic. Syndr. 2020. [CrossRef] [PubMed]

43. Yen, Y.F.; Jen, I.; Chen, M.; Chuang, P.H.; Liu, Y.L.; Sharp, G.B.; Chen, Y. Association of Cytomegalovirus End-Organ Disease with Stroke in People Living with HIV/AIDS: A Nationwide Population-Based Cohort Study. PLoS ONE 2016, 11, e0151684. [CrossRef]

44. Behrouz, R.; Topel, C.H.; Seifi, A.; Birnbaum, L.A.; Brey, R.L.; Misra, V.; Napoli, M.D. Risk of intracerebral hemorrhage in HIV/AIDS: A systematic review and meta-analysis. J. Neurovirol. 2016, 22, 634-640. [CrossRef] [PubMed]

45. Althoff, K.N.; Gebo, K.A.; Moore, R.D.; Boyd, C.M.; Justice, A.C.; Wong, C.; Lucas, G.M.; Klein, M.B.; Kitahata, M.M.; Crane, H.; et al. Contributions of traditional and HIV-related risk factors on non-AIDS-defining cancer, myocardial infarction, and end-stage liver and renal diseases in adults with HIV in the USA and Canada: A collaboration of cohort studies [published correction appears in Lancet HIV. 2019 Apr 2]. Lancet HIV 2019, 6, e93-e104. [CrossRef] [PubMed]

46. Aden, B.; Nosyk, B.; Wittenberg, E.; Schackman, B.R. Health-Related Quality of Life in HIV-Infected and At-Risk Women: The Impact of Illicit Drug Use and Hepatitis C on a Community Preference Weighted Measure. Med. Decis. Mak. 2014, 34, 800-808. [CrossRef]

47. Venturini, A.; Cenderello, G.; Di Biagio, A.; Giannini, B.; Ameri, M.; Giacomini, M.; Montefiori, M.; Setti, M.; Mazzarello, G.; Merlano, C.; et al. Quality of life in an Italian cohort of people living with HIV in the era of combined antiretroviral therapy (Evidence from I.A.N.U.A. study-investigation on antiretroviral therapy). AIDS Care 2017, 29, 1373-1377. [CrossRef]

48. Fuster-RuizdeApodaca, M.J.; Laguía, A.; Safreed-Harmon, K.; Lazarus, J.V.; Cenoz, S.; Del Amo, J. Assessing quality of life in people with HIV in Spain: Psychometric testing of the Spanish version of WHOQOL-HIV-BREF. Health Qual. Life Outcomes 2019, 17, 144. [CrossRef]

49. Emuren, L.; Welles, S.; Evans, A.A.; Polansky, M.; Okulicz, J.F.; Macalino, G.; Agan, B.K. Health-related quality of life among military HIV patients on antiretroviral therapy. Infectious Disease Clinical Research Program HIV Working Group. PLoS ONE 2017, 12, e0178953. [CrossRef]

50. Préau, M.; Marcellin, F.; Carrieri, M.P.; Lert, F.; Obadia, Y.; Spire, B. Health-related quality of life in French people living with HIV in 2003, results from the national ANRS-EN12-VESPA Study. AIDS 2007, 21 (Suppl. 1), S19-S27. [CrossRef]

51. Fumaz, C.R.; Larrañaga-Eguilegor, M.; Mayordomo-López, S.; Gómez-Martínez, S.; González-García, M.; Ornellas, A.; Fuster, M.J.; Remor, E.; Ballester-Arnal, R. Health-related quality of life of people living with HIV infection in Spain: A gender perspective. AIDS Care 2019, 31, 1509-1517. [CrossRef] [PubMed] 
52. Protopopescu, C.; Marcellin, F.; Spire, B.; Préau, M.; Verdon, R.; Peyramond, D.; Raffi, F.; Chene, G.; Leport, C.; Carrieri, M.P. Health-related quality of life in HIV-1-infected patients on HAART: A five-years longitudinal analysis accounting for dropout in the APROCO-COPILOTE cohort (ANRS CO-8). Qual. Life Res. 2007, 16, 577-591. [CrossRef]

53. Nieuwkerk, P.T.; Hillebrand-Haverkort, M.E.; Vriesendorp, R.; Frissen, P.H.; de Wolf, F.; Sprangers, M.A.; ATHENA Study Group. Quality of life after starting highly active antiretroviral therapy for chronic HIV-1 infection at different CD4 cell counts. J. Acquir. Immune Defic. Syndr. 2007, 45, 600-601. [CrossRef]

54. Anis, A.H.; Nosyk, B.; Sun, H.; Guh, D.P.; Bansback, N.; Li, X.; Barnett, P.G.; Joyce, V.; Swanson, K.M.; Kyriakides, T.C.; et al. Quality of life of patients with advanced HIV/AIDS: Measuring the impact of both AIDS-defining events and non-AIDS serious adverse events. J. Acquir. Immune Defic. Syndr. 2009, 51, 631-639. [CrossRef] [PubMed]

55. Liu, C.; Johnson, L.; Ostrow, D.; Silvestre, A.; Visscher, B.; Jacobson, L.P. Predictors for lower quality of life in the HAART era among HIV-infected men. J. Acquir. Immune Defic. Syndr. 2006, 42, 470-477. [CrossRef]

56. Emuren, L.; Welles, S.; Macalino, G.; Evans, A.A.; Polansky, M.; Ganesan, A.; Colombo, R.E.; Agan, B.K. Predictors of health-related quality of life among military HIV-infected individuals. Qual. Life Res. 2020. [CrossRef]

57. World Health Organization. Guidelines for Managing Advanced HIV Disease and Rapid Initiation of ART. Available online: https:/ / www.who.int/hiv/pub/guidelines/advanced-HIV-disease/en/ (accessed on 5 February 2021).

58. British HIV Association. BHIVA Guidelines for the Routine Investigation and Monitoring of Adult HIV-1-Positive Individuals. Available online: https:/ / www.bhiva.org/file/DqZbRxfzlYtLg/Monitoring-Guidelines.pdf (accessed on 5 February 2021). 